Original Research Paper

\title{
Pelatihan Pembuatan Tempe Kedelai Hitam Pengrajin Tempe Kelurahan Abian Tubuh
}

\author{
Seto Priyambodo ${ }^{1 *}$, Ima Arum Lestarini ${ }^{1}$, Basuki $\mathbf{R}^{1}$, Rifana Cholidah ${ }^{1}$, Palgunadi $^{1}$ \\ ${ }^{1}$ Fakultas Kedokteran, Universitas Mataram
}

*Corresponding Author: Seto Priyambodo, Fakultas Kedokteran, Universitas Mataram, Indonesia; Email: setopriyambodo97@gmail.com

\begin{abstract}
Abstrak: Kelurahan Abian tubuh merupakan sentra produsen tempe dan tahu di kota Mataram. Masyarakat mengandalkan pendapatan dari penjualan tahu dan tempe yang mereka buat. Selama ini mereka mempunyai pangsa pasar harian yang sudah dapat diperkirakan sehingga dalam hal produksi mereka membuat sesuai dengan permintaan dari konsumen. Permasalahan di masyarakat pengrajin tempe di kelurahan Abian Tubuh adalah terbatasnya pangsa pasar tempe sehingga diperlukan strategi untuk membuat peningkatan kualitas kandungan gizi produk tempe agar dapat mentarget penjualan ke sasaran pangsa pasar yang lebih luas. Solusi yang ditawarkan adalah dengan melakukan diversifikasi produk tempe dengan bahan kedelai hitam, yang diketahui mempunyai kandungan isoflavon yang lebih tinggi di banding kedelai kuning, sehingga diharapkan kualitas gizi tempe yang diproduksi akan lebih bagus dan dapat memperluas pemasaran..
\end{abstract}

Kata kunci: Tempe, Kedelai hitam, Abian Tubuh

\section{Pendahuluan}

Kelurahan Abian tubuh merupakan sentra produsen tempe dan tahu di kota Mataram. Masyarakat mengandalkan pendapatan dari penjualan tahu dan tempe yang mereka buat. Selama ini mereka mempunyai pangsa pasar harian yang sudah dapat diperkirakan sehingga dalam hal produksi mereka membuat sesuai dengan permintaan dari konsumen.

Permasalahan di masyarakat pengrajin tempe di kelurahan Abian Tubuh adalah terbatasnya pangsa pasar tempe sehingga diperlukan strategi untuk membuat peningkatan kualitas kandungan gizi produk tempe agar dapat mentarget penjualan ke sasaran pangsa pasar yang lebih luas.

Salah satu tanaman tradisional yang biasa dibudidayakan di Indonesia adalah kedelai hitam (Glycine max L. Merr). Di dalam kedelai hitam terkandung zat-zat yang dapat berefek menurunkan kadar lipid. Kedelai hitam memiliki kelebihan dibandingkan kedelai kuning karena kandungan isoflavonnya yang lebih tinggi. Banyak penelitian mengenai aktivitas kedelai hitam (dalam bentuk olahan utuh, ekstrak, fermentasi ataupun ekstrak dari produk fermentasi) untuk mengurangi kadar lipid baik pada hewan coba, maupun pada manusia. Penelitian-penelitian tersebut diantaranya: efek terhadap penurunan rasio kolesterol LDL/HDL darah pada tikus yang diberi diet tinggi lemak, penghambatan uptake asam lemak dan trigliserida (Do KR , 2011) dan efek terhadap komponen metabolik pro obesitas (Kim MJ, 2012). Selain itu penelitian klinis dengan menggunakan bahan kandungan bioaktif utama yang terdapat pada kedelai hitam yaitu isoflavon terbukti efektif untuk digunakan sebagai terapi pada hiperlipidemia (Gosavi T J, 2014).

\section{Metode Pelaksanan}

Untuk meningkatan pengetahuan serta keterampilan kelompok pengrajin tempe tentang pentingnya kandungan antioksida /isoflavon dalam tempe kedelai hitam, maka dilakukan pelatihan terhadap kelompok pengrajin tempe sasaran. Materi pelatihan yang diberikan tentang: a) pentingnya 
asupan makanan dengan kandungan antioksidan/isoflavon, b) metode pembuatan tempe dengan kedelai hitam.

Pelaksanaan kegiatan dimulai dengan permohonan ijin oleh tim pengabdian kepada pihak terkait di kelurahan abian tubuh. Tim pengabdian menentukan kelompok sasaran kegiatan pengabdian yaitu pengusaha tempe bapak irul (produsen tempe pohon kedelai).

Kegiatan pengabdian ini dilaksanakan pada 21 oktober 2018 di rumah bapak Irul kelurahan abian tubuh. Kegiatan dihadiri oleh 7 orang yang meliputi para pekerja di kelompok pengrajin tempe serta tim dari universitas mataram.

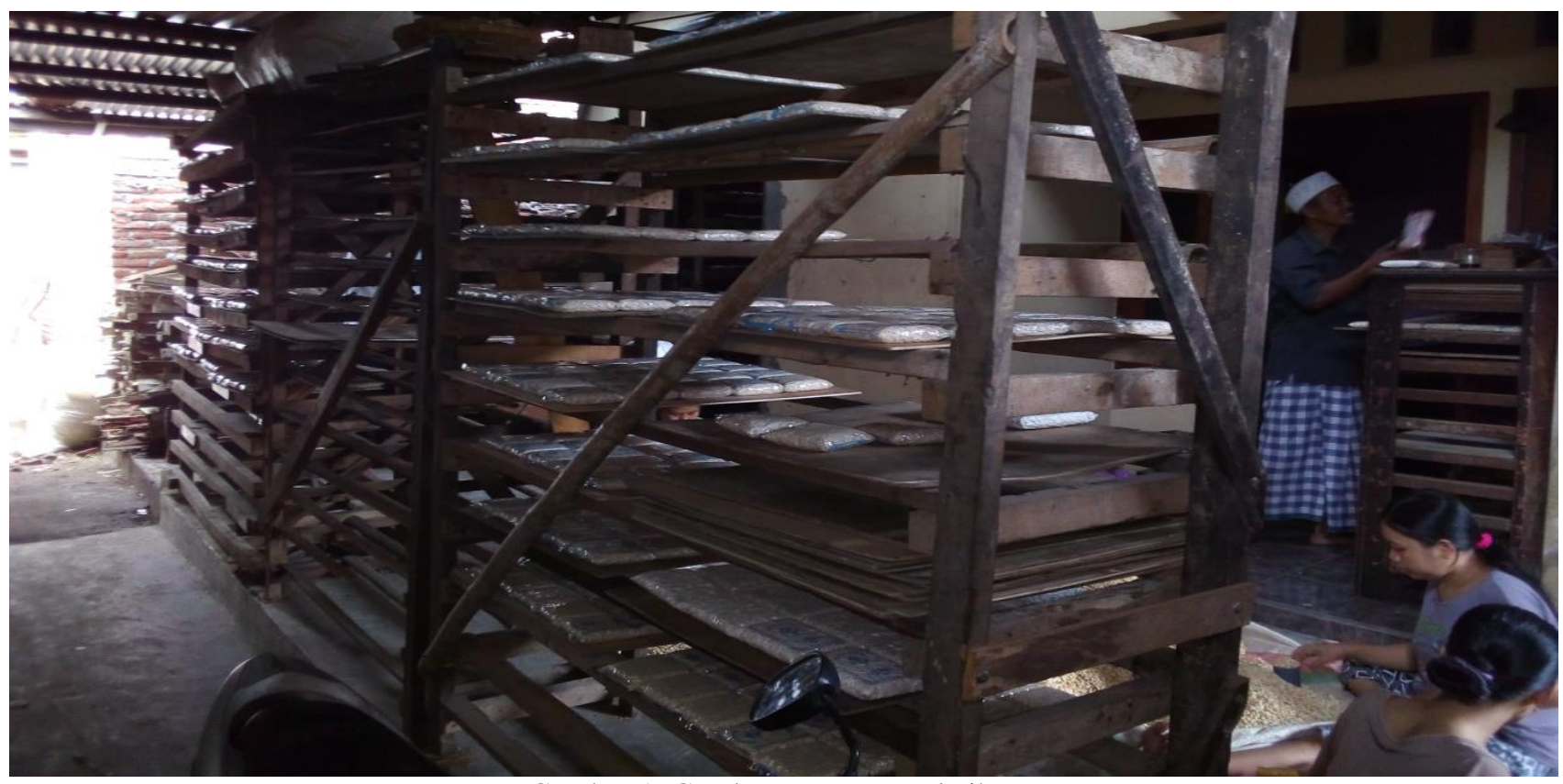

Gambar 1. Gambaran tempat pelatihan

Kegiatan dimulai dengan pemaparan tentang kandungan gizi kedelai hitam dan perannnya terhadap kesehatan dan berdiskusi tentang hal tersebut kemudian dilanjutkan dengan metode pembuatan tempe kedelai hitam.

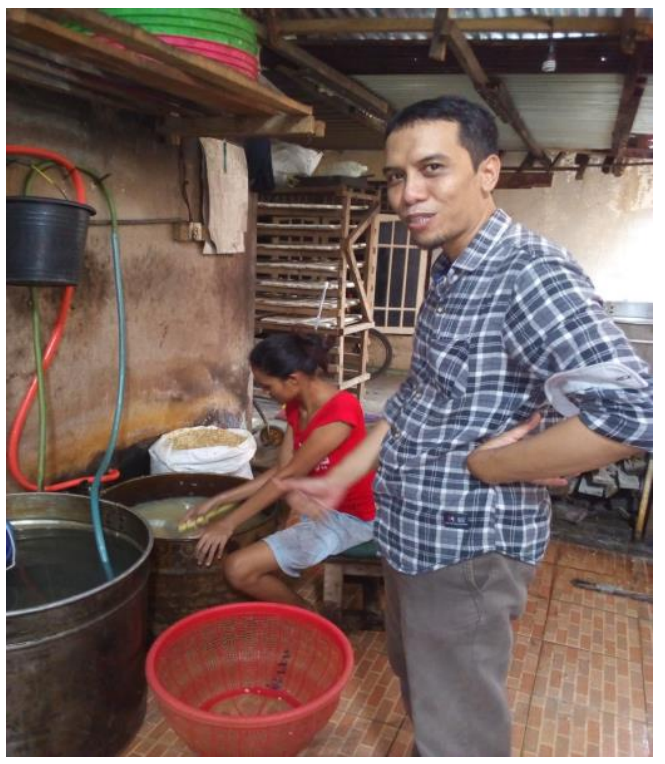

Gambar 2. Proses pembuatan tempe

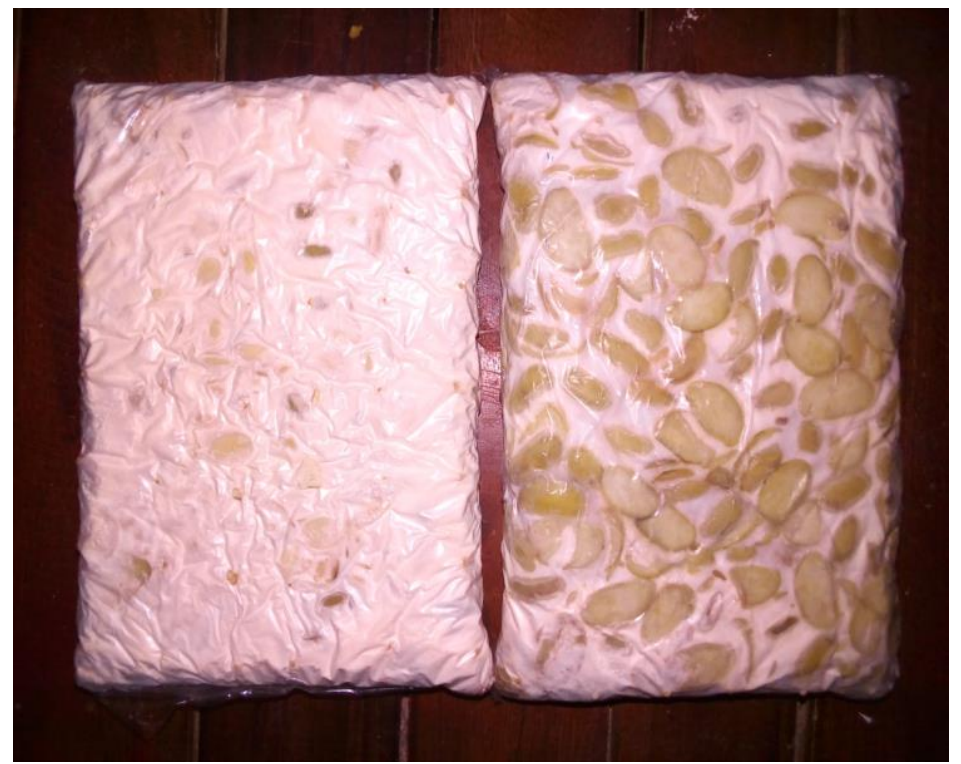

Gambar 3. Hasil tempe kedelai hitam 
Setelah itu kegiatan dilanjutkan dengan diskusi bersama ketua kelompok untuk menilai apakah proses yang sudah dilaksanakan dapat dilanjtukan untuk skala produksi.

\section{Hasil dan Pembahasan}

Di Indonesia, berdasarkan Survei Kesehatan Rumah Tangga (SKRT), jumlah penderita penyakit jantung koroner terus meningkat dari waktu ke waktu. Penyakit jantung koroner saat ini menjadi penyebab kematian yang utama dengan peningkatan prosentase dari tahun ke tahun seiring dengan perkembangan zaman serta perubahan pola dan gaya hidup termasuk resiko pada masa anak. Salah satu faktor resiko utama dari penyakit jantung koroner menurut The National Cholesterol Education Program adalah tingginya kadar kolesterol serum dan berbagai fraksinya serta rendahnya kadar kolesterol HDL.

Salah satu tanaman tradisional yang biasa dibudidayakan di Indonesia adalah kedelai hitam (Glycine max L. Merr). Di dalam kedelai hitam terkandung zat-zat yang dapat berefek menurunkan kadar lipid. Kedelai hitam memiliki kelebihan dibandingkan kedelai kuning karena kandungan isoflavonnya yang lebih tinggi. Banyak penelitian mengenai aktivitas kedelai hitam (dalam bentuk olahan utuh, ekstrak, fermentasi ataupun ekstrak dari produk fermentasi) untuk mengurangi kadar lipid baik pada hewan coba, maupun pada manusia. Penelitian-penelitian tersebut diantaranya: efek terhadap penurunan rasio kolesterol LDL/HDL darah pada tikus yang diberi diet tinggi lemak (Priyambodo, 2001), penghambatan uptake asam lemak dan trigliserida (Kyoung Rok Do, 2011) dan efek terhadap komponen metabolik pro obesitas (Muray R, 2003). Selain itu penelitian klinis dengan menggunakan bahan kandungan bioaktif utama yang terdapat pada kedelai hitam yaitu isoflavon terbukti efektif untuk digunakan sebagai terapi pada hiperlipidemia. Untuk pengembangan tempe kedelai hitam ke depannya diharapkan terstandarisasi kandungan isoflavonnya.

Pada pelatihan sebelumnya penulis juga memberikan pelatihan tentang pembuatan tempe kemiri yang didapatkan hasil sebagai berikut :

Tabel 1. Hasil analisa GCMS

$\begin{array}{rrrr}\text { Peak\# } & \text { R.Time } & \text { I.Time } & \text { F.Time } \\ 1 & 10.419 & 10.400 & 10.450 \\ 2 & 11.089 & 11.070 & 11.110 \\ 3 & 11.301 & 11.285 & 11.330 \\ 4 & 11.890 & 11.865 & 11.920 \\ 5 & 11.961 & 11.925 & 11.985 \\ 6 & 12.025 & 11.985 & 12.150 \\ 7 & 12.115 & 12.100 & 12.130 \\ 8 & 12.290 & 12.270 & 12.320 \\ 9 & 12.347 & 12.320 & 12.380 \\ 10 & 12.475 & 12.445 & 12.535 \\ 11 & 12.559 & 12.535 & 12.580 \\ 12 & 12.658 & 12.580 & 12.695 \\ 13 & 12.711 & 12.695 & 12.960 \\ 14 & 13.361 & 13.325 & 13.395 \\ 15 & 13.424 & 13.395 & 13.440 \\ 16 & 13.455 & 13.440 & 13.475 \\ 17 & 13.535 & 13.475 & 13.620 \\ 18 & 14.385 & 14.350 & 14.425 \\ 19 & 15.836 & 15.770 & 15.895 \\ 20 & 15.929 & 15.895 & 16.025 \\ & & & \end{array}$

\begin{tabular}{rrrr} 
Area & \multicolumn{3}{c}{ Peak Report TIC } \\
Area $\%$ & Height & Height\% \\
508241 & 0.12 & 531935 & 0.30 \\
139835 & 0.03 & 152519 & 0.08 \\
187357 & 0.05 & 193872 & 0.11 \\
3401977 & 0.84 & 3717474 & 2.06 \\
291731 & 0.07 & 191039 & 0.11 \\
41139029 & 10.12 & 33955627 & 18.84 \\
75972 & 0.02 & 110608 & 0.06 \\
170856 & 0.04 & 148700 & 0.08 \\
236500 & 0.06 & 195088 & 0.11 \\
29328651 & 7.21 & 17705420 & 9.82 \\
1090402 & 0.27 & 1081895 & 0.60 \\
280159423 & 68.89 & 99222458 & 55.05 \\
31743754 & 7.81 & 16756753 & 9.30 \\
576222 & 0.14 & 295917 & 0.16 \\
456163 & 0.11 & 282228 & 0.16 \\
253812 & 0.06 & 189674 & 0.11 \\
1330462 & 0.33 & 542464 & 0.30 \\
284978 & 0.07 & 142479 & 0.08 \\
12120811 & 2.98 & 3884303 & 2.16 \\
3162009 & 0.78 & 933344 & 0.52 \\
406658185 & 100.00 & 180233797 & 100.00
\end{tabular}

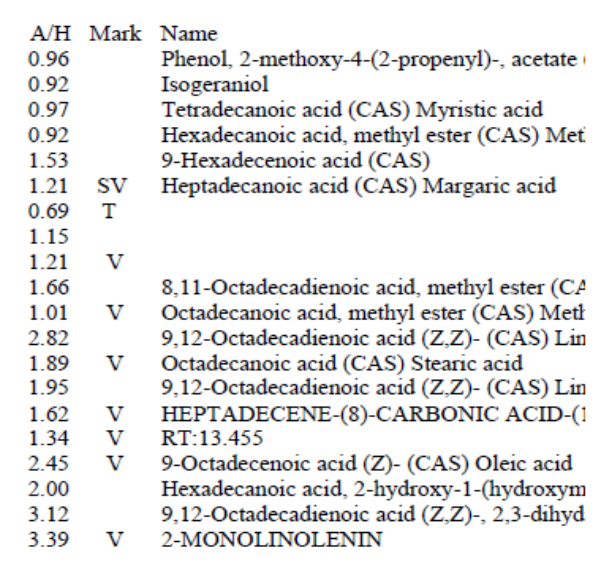

Didapatkan hasil komposisi asam lemak utama pada tempe kemiri berupa Linoleic Acid (LA) 68,89\%, Heptadecanoic Acid 10,12\% dan Stearic Acid 7,81\% .Penambahan kemiri $25 \%$ pada tempe dapat meningkatkan kandungan Heptadecanoic Acid yang dapat berpotensi digunakan sebagai nutrisi fungsional pada pre-diabetes

\section{Kesimpulan}

Untuk meningkatkan kualitas gizi tempe dapat di tambahkan modifikasi kedelai hitam .Kandungan isoflavon yang lebih tinggi pada kedelai hitam diharapkan dapat meningkatkan nilai jualnya. Selain itu diperlukan adanya proses yang terstandarisasi agar kandungan gizinya dapat 
terstandar sehingga dapat menambah nilai jualnya/dapat memperluas pemasaran.

\section{Daftar Pustaka}

Do KR, Jeun JA, Houng S-J, Jun H-j, Lee JH, Jia Y, Lee S-J. Soybean (Glycine max L. Merr.) Hexane Extracts Inhibit Cellular Fatty Acid Uptake by Reducing the Expression of Fatty Acid Transporters. Food Sci. Biotechnol. 20: 237-242, 2011

Gosavi TP et al. A Comprehensive Metaanalysis and Systematic Review on Effect of Genistein on Metabolic Syndrome, Pharmacologia, 2014

Kim MJ et al. Obesity-Related Metabolomic Analysis of Human Subjects in Black Soybean Peptide Intervention Study by Ultraperformance Liquid Chromatography and Quadrupole-Time-of-Flight Mass Spectrometry, Journal of Obesity ,2013

Murray, R.K., Granner, D.K., Mayes.P.A, Rodwell, V.W., 2003. Biokimia Harper Ed. 25. Jakarta: EGC

Priyambodo S. 2001. Pengaruh pemberian kedelai hitam terhadap rasio HDL?LDL tikus putih yang diberi diet tinggi lemak. 